\title{
The Europol and Eurojust Project on Joint Investigation Teams*
}

\author{
Lisa Horvatits · Bart de Buck
}

Published online: 1 June 2007

(C) ERA 2007

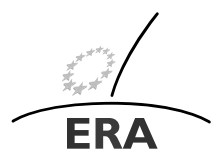

EUROPÄISCHE RECHTSAKADEMIE ACADEMY OF EUROPEAN LAW ACADEMIE DE DROIT EUROPEEN ACCADEMIA DI DIRITTO EUROPEO TRIER - TREVES - TREVIRI

\begin{abstract}
In a common project, Eurojust and Europol produced a guide to the EU Member States' legislation on Joint Investigation Teams which gives an overview of the legal possibilities in all EU Member States to set up Joint Investigation Teams pursuant to Article 13 of the EU's 2000 MLA Convention, as well as the means by which Europol and Eurojust can support these teams under each legal framework. The following article outlines the initiation of the project, its execution and the difficulties encountered. Finally, the guide itself will be presented.
\end{abstract}

Keywords Mutual Legal Assistance $\cdot$ Europol $\cdot$ Eurojust $\cdot$ Joint Investigation Teams

\section{The initiation of the Project}

In the second semester of 2004, the Legal Affairs Unit of Europol started to collect the national legislation implementing the Framework Decision on Joint Investigation Teams (JITs). ${ }^{1}$ The goal of this exercise was to collate all national 'JIT-related legislation' with the aim of producing an overview of the different legal possibilities in all

\footnotetext{
Lisa Horvatits, Project Team Member EUROJUST

Maanweg 174, 2516 AB The Hague, Netherlands

e-mail: lhorvatits@eurojust.europa.eu

Bart de Buck, First Officer - Legal Affairs

EUROPOL

P.O. Box 908 50, 2509 LW The Hague, Netherlands

e-mail: bart.debuck@europol.europa.eu
}

\footnotetext{
* This paper is based on the presentations given by the authors at the ERA conference on Joint Investigation Teams: The Fight Against Serious Cross-border Organised Crime and Terrorism, 17-19 May 2006 in Trier.
}

1) Framework Decision of 13 June 2002 on Joint Investigation Teams, OJ L162 of 20.6. 2002, p. 1. 
EU Member States to set up JITs. A first phase was intended to search for all documentation on JITs available in the Member States, including national implementing legislation, and to compile it into a documentation folder per country. At that time, many Member States had not yet adopted JIT legislation, even though the deadline for the implementation of the Framework Decision had already elapsed. A second step in the project was drafting a questionnaire assembling the main elements of the JIT concept outlined in Article 13 of the 2000 MLA Convention. ${ }^{2}$ This questionnaire was intended to serve as a grid for describing all aspects regarding the setting up, composition and functioning of a JIT in each Member State. Eurojust joined the venture in the first half of 2005 and a formal project structure was set up to build on the work done by Europol and a project initiation document was agreed upon between Europol and Eurojust. A project team was installed, consisting of representatives of Eurojust and Europol, supervised by a Project Board (the Eurojust-Europol Steering Committee and heads of Legal Service). The project is managed by Europol and Eurojust in full partnership.

The scope was approved: to produce a guide to EU Member States' legislation on Joint Investigation Teams which will give an overview of the legal possibilities in all EU Member States to set up Joint Investigation Teams in the sense of Article 13 of the 2000 MLA Convention, as well as the means by which Europol and Eurojust can support these teams under each legal framework. The overview should provide a clear picture of how the principles of 'Article 13 JITs' are regulated in all Member States.

\section{The execution of the project}

\subsection{Documentation}

The project was divided into four phases, starting with a documentation phase in which all relevant information on JITs for each Member State was gathered with the aim of completing a set of documentation comprising all relevant information on JITs for each Member State. The information consisted of national legislation on JITs, excerpts of substantive and procedural criminal law (if reference was made to it), explanatory memoranda, ministerial directives and/or prosecutor guidelines, background information, etc.

In order to maintain an overview of all documents, the team used a documentation management system, which means that all documents were stored at Eurojust as well as at Europol following a 'mirror system'.

\subsection{Draft model questionnaire}

A second phase consisted of drafting a questionnaire as a template containing all aspects of the JIT concept and thus allowing for a fairly accurate description of it

\footnotetext{
2) Council Act of 29 May 2000 establishing in accordance with Article 34 of the Treaty on European Union the Convention on Mutual Assistance in Criminal Matters between the Member States of the European Union, OJ C197 of 12.7.2000, p. 1. The Convention entered into force for the ratifying Member States on 23 August 2005. For further details or notification, see Gualtieri and Helmberg in this issue.
} 
(analysing primarily legal aspects in relation to setting up, participation and functioning) in all (then) 25 Member States. ${ }^{3}$ The use of the questionnaire would also facilitate the comparison between the implementing legislation of the Member States. The questionnaire itself contains the main elements incorporated in Article 13 of the 2000 MLA Convention or the Framework Decision on JITs and is divided into nine chapters:

- legal basis to set up a JIT;

- setting up a JIT;

- composition of a JIT;

- JIT operations;

- information management;

- formal participation of non-EU States;

- assistance of non-EU States (or Member States);

- participation in the activities of a JIT by representatives of Third States and international bodies (such as Eurojust, Europol, OLAF);

- civil and criminal liability.

The questionnaire also contains other questions such as the reference to the Model Agreement for setting up JITs ${ }^{4}$ in national law, the right of seconded members to carry weapons, the main procedural laws applicable to JIT activities on national soil, the use of information obtained through a JIT as evidence (with the following subquestions: Under which conditions can information obtained through a foreign JIT be used in court proceedings? Should the information gathered be confirmed via the normal mutual legal assistance procedures in order to be valid in national court proceedings? Are there any limitations on information introduced by a seconded member to a national JIT to be used in national court proceedings?), the testimony of members of JITs in court proceedings, the participation of non-EU States as formal members of a Joint Investigation Team (with the sub-question whether some countries intend to include Third States in the setting up of JITs when their national law regulates the setting up of a JIT 'with foreign states'and not specifically Member States?) and the participation of Eurojust, Europol and OLAF.

\subsection{Completing the questionnaires}

The project team was able, in a third phase, to complete twenty-three questionnaires using all relevant documentation available. The project team analysed the national legislation on JITs using the set of documentation per country and then drafted responses to the questionnaire for each Member State. In an informal check of the responses, Europol and Eurojust cross-checked the drafted answers. As regards the two remaining countries, Greece only has draft legislation (the questionnaire was provisionally completed) and Italy does not, at present, have legislation on JITs.

Bulgaria and Romania joined the European Union on 1 January 2007. The project team is currently completing the questionnaires for Bulgaria and Romania.

\footnotetext{
3) Bulgaria and Romania joined the European Union on 1 January 2007 (now: 27 Member States). The Project Team is currently completing the questionnaires for Bulgaria and Romania.

4) Council Recommendation of 8 May 2003 on a model agreement for setting up a Joint Investigation Team, OJ C121 of 23.5.2003, p. 1.
} 


\subsection{Verification and consolidation}

Finally, the questionnaires were checked during a verification and consolidation phase, in which the completed questionnaires were initially discussed with the Eurojust National Members in interviews. The latter provided additional information, checked the draft answers and, where necessary the available translation of the national legislation. Following this, the questionnaires were amended where necessary, before being sent to the Member States for review. The project team collected all answers from the Member States, and finalised the guide.

\section{Difficulties encountered in the course of the project}

Several difficulties were encountered during work on the project:

\subsection{Documentation}

The search for available information on JITs in the Member States was more difficult than expected. There was very little documentation accessible on JITs in the Member States and many of them had not adopted JIT legislation at the time of the project team's search. Moreover, it was difficult to trace the applicable legal texts, especially in those countries where the law implementing the JIT concept refers to other national legislation or where the implementation of the JIT concept is fragmented over several legal acts, i.e. in the substantive and/or procedural criminal law code or statutes. Additional information could sometimes be taken from ministerial directives or guidelines. However, these were more difficult to find.

\subsection{Understanding the different legal systems}

At present, there are 29 different legal systems within the European Union, taking into account three different systems in the UK. It was a demanding task to understand the different approaches of the Member States in establishing a framework within their legislation to implement the JIT instrument. In this regard, while some countries have adopted specific laws on JITs or have inserted JIT provisions in their Code of Criminal Procedure, others have simply referred to the direct applicability of the 2000 MLA Convention in their national legal order. When it comes to other sources of JIT-related provisions or JIT-related background information, such as Home Office Circulars, $B e$ leidsregels, prosecutorial guidelines or recommendations, it was difficult to find out whether these are considered as law or are merely seen as supportive documents. Furthermore, the common law and civil law systems differ considerably and the project team needed some time to become acquainted with the methods of the common law system, e.g. in the UK, where only a few provisions required implementation.

\subsection{Translation}

A proper research of the legislation in the Member States is always dependent on the available working documents. Since there are 23 official languages within the 
European Union, the project team required a translation of the legislation for most countries. Only a few countries had a translation of their implementing legislation available and even then it often remained unclear whether this translation was an official or unofficial translation. Some translations were furthermore of a poor quality and the project team had to be careful to avoid misinterpretations of the provisions. The project team received the legislation from most countries in the original language version and sent it, in turn, to a translation service.

\subsection{Update of the national legislation}

Neighter 2000 MLA Convention nor the 2002 Framework Decision on JITs has yet been ratified and implemented in all Member States. During the project the project team had to amend its answers to the questionnaires regularly to keep the information on ratification or implementation updated. Given the difficulty in obtaining information on amendments to the national JIT legislation, the project team sought the information by indirect methods, e.g. from Eurojust National Members. As already stated, the project team is currently completing the questionnaires for Bulgaria and Romania.

\section{The result: the guide}

The finalised guide was presented at the second meeting of the national experts on JITs held at Europol on 10 November 2006. It is important to emphasise that the guide does not intend to interfere in any way with the responsibilities of the European Commission and the Council to assess the extent to which the Member States have complied with the Framework Decision and does not constitute an official assessment of the degree of implementation.

The purpose of the guide is rather informative, i.e. to offer information on Member States' legislation on JITs and to provide an overview of how the principles of Article 13 JITs are regulated in all 27 Member States.

The guide is a working document and is currently being updated. One aspect of current work worth mentioning is the effort being made to gather official English translations of JIT related legislation (if at all available). The updated guide will be published on the homepages of Eurojust as well as Europol. ${ }^{5}$

It has moreover recently been agreed that a permanent Europol-Eurojust Team will be created. It will not only ensure follow-up to the JITs project (guide) but ties in with related initiatives aimed at supporting the network of the national experts on JITs (managing the webpage and organisation of the annual JIT experts meetings) and the project of operational guidelines on how to set up JITs.

Eurojust and Europol hope that the guide will contribute to the awareness of the concept of JITs and provide valuable assistance to the national authorities of the Member States in the setting up of such teams.

\footnotetext{
5) www.europol.europa.eu and www.eurojust.europa.eu.
} 